\title{
Starch biotransformation into isomaltooligosaccharides using thermostable alpha-glucosidase from Geobacillus stearothermophilus
}

Peng Chen Corresp., ${ }^{1,2}$, Ruixiang Xu ${ }^{1}$ ， Jianhui Wang ${ }^{2}$, Zhengrong Wu ${ }^{1}$, Lei Yan ${ }^{3}$, Wenbin Zhao ${ }^{1}$, Yuheng Liu

1, Wantong Ma ${ }^{1}$, Xiaofeng Shi ${ }^{4}$, Hongyu Li ${ }^{\text {corresp. } 1}$

${ }^{1}$ School of Pharmacy, Lanzhou University, Lanzhou, Gansu, PR. China

2 School of Medicine, Yale University, New Haven, Connecticut, United States

${ }^{3}$ College of Life Science and Technology, Heilongjiang August First Land Reclamation University, Heilongjiang, PR. China

${ }^{4}$ Gansu Academy of Medical Science, Lanzhou, PR. China

Corresponding Authors: Peng Chen, Hongyu Li

Email address: chenpeng@lzu.edu.cn, lihy@lzu.edu.cn

The present study first identified the biotransformation of starch as a novel preparation method was investigated using the alpha-transglucosidase-producing Geobacillus stearothermophilus (G. stearothermophilus) U2. Subsequently, 5 L- and 20 L-scale fermentations were performed. After isolation and purification, liquid alpha-glucosidase preparations were obtained. Through covalent cross-linking and adsorption cross-linking using chitosan as the carrier and glutaraldehyde as the crosslinking agent, the conditions for immobilization of alpha-glucosidase on chitosan were determined. Moreover, Isomaltooligosaccharides (IMOs) were then prepared using chitosan membraneimmobilized alpha-glucosidase, beta-amylase, pullulanase, fungal alpha-amylase and starch as substrate. The mixed syrup that contained IMOs was evaluated and analyzed by thin-layer chromatography and high-performance liquid chromatography (HPLC). In addition, small-scale preparation of IMOs was performed. These results are a strong indication that the alpha-transglucosidase-producing G. stearothermophilus as a potential application technique can be successfully used to prepare industrial IMOs. 
1 Starch biotransformation into isomaltooligosaccharides using thermostable alpha-glucosidase

2 from Geobacillus stearothermophilus

3 Peng Chen ${ }^{1,2}$, Ruixiang $\mathrm{Xu}^{1}$, Jianhui Wang ${ }^{2}$, Zhengrong $\mathrm{Wu}^{1}$, Lei $\mathrm{Yan}^{3}$, Wenbin Zhao ${ }^{1}$, Yuheng

$4 \quad \mathrm{Liu}^{1}$, Wantong $\mathrm{Ma}^{1}$, Xiaofeng $\mathrm{Shi}^{4}$, Hongyu $\mathrm{Li}^{1, *}$

$5 \quad{ }^{1}$ School of Pharmacy, Lanzhou University, No. 199 Donggang West Road, Lanzhou, 730020, PR

6 China

$7{ }^{2}$ School of Medicine, Yale University, No. 310 Cedar Street, New Haven, 06510, USA

$8{ }^{3}$ College of Life Science and Technology, Heilongjiang Bayi Agricultural University, Daqing,

9 163319, PR China

$10{ }^{4}$ Gansu Academy of Medical Science, No. 2 Xiaoxihu East Road, Lanzhou 730050, PR China

* Correspondence and requests for materials should be addressed to P. C. (chenpeng@1zu.edu.cn) or H. Y. L. (lihy@lzu.edu.cn). Tel. \& fax: +86 9318915686. 
12 Abstract: The present study first identified the biotransformation of starch as a novel preparation 13 method was investigated using the alpha-transglucosidase-producing Geobacillus 14 stearothermophilus (G. stearothermophilus) U2. Subsequently, 5 L- and 20 L-scale fermentations 15 were performed. After isolation and purification, liquid alpha-glucosidase preparations were 16 obtained. Through covalent cross-linking and adsorption cross-linking using chitosan as the carrier 17 and glutaraldehyde as the crosslinking agent, the conditions for immobilization of alpha18 glucosidase on chitosan were determined. Moreover, Isomaltooligosaccharides (IMOs) were then 19 prepared using chitosan membrane-immobilized alpha-glucosidase, beta-amylase, pullulanase, 20 fungal alpha-amylase and starch as substrate. The mixed syrup that contained IMOs was evaluated 21 and analyzed by thin-layer chromatography and high-performance liquid chromatography 22 (HPLC). In addition, small-scale preparation of IMOs was performed. These results are a strong 23 indication that the alpha-transglucosidase-producing G. stearothermophilus as a potential 24 application technique can be successfully used to prepare industrial IMOs. 


\section{Introduction}

Alpha-glucosidases (EC3.2.1.20) belong to the starch hydrolase family and mainly exert their functions outside of cells (Hirschhorn et al., 2002). Alpha-glucosidase hydrolyzes the alphaglycosidic bond from the non-reducing end of the polysaccharide substrate, releasing alpha-Dglucose. Alpha-glucosidases are generally categorized as hydrolytic enzymes (class 3) and mainly hydrolyze disaccharides, oligosaccharides, aromatic glycosides, sucrose and polysaccharides (Mohamed Sham Shihabudeen et al., 2011;Madariaga-Mazon et al., 2016). In addition, alphaglucosidase mediates transglycosidation (Johnson et al., 2016). The enzyme converts the alpha-1,4glucosidic bond in polysaccharides into an alpha-1,6-glycosidic bond or other forms of linkage (Benayad et al., 2016), resulting in the formation of non-fermentable isomaltooligosaccharides (IMOs) or sugar esters/glycopeptides (Kaneko et al., 1995). In the 1980s, Japanese scientists first isolated alpha-glucosidase-producing fungal strains of Aspergillus niger. Since then, alphaglucosidase has been widely used. In the starch and sugar industry, alpha-glucosidase is mainly used, together with alpha-amylase, in the production of high-glucose syrup.

Alpha-glucosidase is also used to produce IMOs that function as bifidus factors (Lambert and Zilliken, 1965). IMOs, also known as branched oligosaccharides, are a type of syrup produced by full enzymatic processing using starch as the raw material (Kaneko et al., 1995). IMOs consist of 2-10 glucose residues and contain at least one alpha-1,6-glycosidic bond and the remaining bonds in IMO molecules are all alpha-1,4-glycosidic bonds. Commercial IMOs are a class of syrups that contain isomaltose, panose, isomaltotriose and branched oligosaccharides composed of more than four sugar residues (Chockchaisawasdee and Poosaran, 2013). The branched oligosaccharides account for more than $50-55 \%$ of the total sugar content. Other sugars in commercial IMOs include glucose and maltose. The sweetness of commercial IMOs is $40-50 \%$ of the sweetness of sucrose. 
IMOs promote the growth of probiotics such as Bifidobacterium and Lactobacillus, adjust the balance of intestinal flora, promote peristalsis, prevent and relieve constipation and diarrhea, prevent dental caries, and inhibit the growth of harmful intestinal bacteria and the formation of decaying substances. Through the proliferation of Bifidobacterium and other probiotics, IMOs indirectly exert many health protection functions, including anti-tumor function, liver protection, promotion of vitamins, improved immunity, and prevention of cardiovascular and cerebrovascular diseases (Maina et al., 2011). However, most of the alpha-glucosidases reported in the literature cannot be used for the industrial production of oligosaccharides because most alpha-glucosidases are not thermostable. Therefore, to meet different production requirements, the development of novel, high temperature-resistant alpha-glucosidases with good stability is necessary (Khang et al., 2016).

Alpha-glucosidases are widely distributed in nature, and there are a great variety of alphaglucosidases (Xiao et al., 2012). These alpha-glucosidases display distinct characteristics and exist in almost all organisms. Among the alpha-glucosidases that have been studied, the vast majority are derived from microorganisms while only a few are from plants and animals. Aspergillus niger (Liu et al., 2013;Hatano et al., 2017), Aspergills foetidus, Bacillus licheniformis (Nawaz et al., 2014;Nawaz et al., 2016), Pseudoalteromonas sp. (Li et al., 2016), Podospora anserina(Song et al., 2013), Monascus rubervan Tieghem(Chen and Xie, 2008), crenarchaeon Sulfolobus tokodaii (Park et al., 2013), Patinopecten yessoensis (Masuda et al., 2016), Geobacillus sp (Hung et al., 2005)., Malbranchea cinnamomea (Yan et al., 2015), Saccharomyces cerevisiae (Hossain et al., 2016), Xanthophyllomyces dendrorhous (Gutierrez-Alonso et al., 2016), Thermus thermophilus (Zhou et al., 2015), rice seed (Kim et al., 2016), Bifidobacterium adolescentis, Geobacillus stearothermophilus (G. stearothermophilus), Bombyx mori, and Spodoptera frugiperda 
72 (Watanabe et al., 2013) secrete alpha-glucosidase. Among the microorganisms mentioned above, 73 Aspergillus niger produces a larger amount of alpha-glucosidase (Giles-Rivas et al., 2016). Most

of the commercially available alpha-glucosidase products are synthesized through Aspergillus niger-mediated fermentation, such as the transglucosidase from Amano Enzyme Inc., Japan. $G$. stearothermophilus U2 belongs to the thermophilic aerobic bacilli and is a Gram-positive bacterium. Enzymes produced by G. stearothermophilus U2 possess heat-resistant properties. Application of immobilization technology not only enhances enzymatic activity but also achieves better reusability of the enzymes. The fundamental knowledge derived from this study should provide a valuable platform for further investigation into the behavior of G. stearothermophilus involved in starch biotransformation and has potential biotechnological applications in IMOs production.

Therefore, the behavior of alpha-transglucosidase-producing G. stearothermophilus U2 in response to different fermentation conditions were investigated in a series of batch experiments. After isolation and purification, liquid alpha-glucosidase preparations were obtained. Through covalent cross-linking and adsorption cross-linking using chitosan as the carrier and glutaraldehyde as the crosslinking agent, the conditions for immobilization of alpha-glucosidase on chitosan were determined. Starch was liquefied under the action of thermostable alpha-amylase. Liquefied starch was converted into maltose syrup by mesophilic alpha-amylase or bata-amylase. Immobilized alpha-transglucosidase-mediated transglycosylation was then conducted to produce IMOs. The mixed syrup that contained IMOs was tested and analyzed by thin-layer chromatography and high-performance liquid chromatography (HPLC).

\section{Materials and methods}

\subsection{Organism.}


95 A culture of G. stearothermophilus U2 was purchased from the China General Microbiological 96 Culture Collection Center (CGMCC). These bacteria were cultured in nutrient broth medium and

97 used throughout the experiments. The alpha-transglucosidase-producing G. stearothermophilus $98 \mathrm{U} 2$ was grown aerobically at $60^{\circ} \mathrm{C}$ for $17 \mathrm{~h}$ in a medium containing $2 \%(\mathrm{w} / \mathrm{v})$ soluble starch, $2 \%$ peptone, $0.05 \%$ meat extract, $0.2 \%$ yeast extract, $0.3 \% \mathrm{~K}_{2} \mathrm{HPO}_{4}$ and $0.1 \% \mathrm{KH}_{2} \mathrm{PO}_{4}(\mathrm{pH} 7.0)$, as described previously (Suzuki et al., 1984). The corn starch used in the present study was foodgrade and commercially available. All other reagents were analytical grade.

\subsection{Enzyme assay}

Alpha-transglucosidase activity was assayed using p-NPG (P-nitrophenol-alpha-D-glucoside) as substrate (Suzuki et al., 1984). p-NPG was purchased from Sigma-Aldrich Corporation. The standard reaction system $1.0 \mathrm{ml}$ consisted of $33.3 \mathrm{mM}$ phosphate $(\mathrm{pH} 6.8), 2 \mathrm{mM}$-NPG and enzyme. Incubation was for $20 \mathrm{~min}$ at $60^{\circ} \mathrm{C}$. One unit of the activity was defined as the amount of enzyme hydrolyzing $1 \mu \mathrm{mol}$ of the nitrophenyl glucoside/min under the condition described above 108 (Suzuki et al., 1984).

\subsection{Effects of environmental parameters on enzyme production}

110 Fig. 1 shows that the flow-process diagram of starch biotransformation into

111 isomaltooligosaccharides using thermostable alpha-glucosidase from G. stearothermophilus. All

112 batch experiments were carried out with microorganism suspension in 250-ml shake flask at 150

$113 \mathrm{r} / \mathrm{min}$. A series of culture medium were prepared by adding different carbon sources (glucose, 114 starch, maltose, lactose or sucrose; $0.5 \mathrm{~g} / \mathrm{L}$ ), nitrogen sources (beef extract, peptone, yeast powder 115 or ammonium sulfate; $0.5 \mathrm{~g} / \mathrm{L})$ and inorganic salts $\left(\mathrm{MgCl}_{2}, \mathrm{~K}_{2} \mathrm{HPO}_{4}, \mathrm{CaCl}_{2}, \mathrm{MnCl}_{2}, \mathrm{CoCl}_{2}, \mathrm{FeCl}_{2}\right.$, $116 \mathrm{ZnCl}_{2}$ and $\mathrm{CuCl}_{2}$ ) to basic potato medium. After culturing the bacterial strain in different media 117 for $24 \mathrm{~h}$, at $\mathrm{pH} 7.0$ and $37^{\circ} \mathrm{C}$ with shaking $(200 \mathrm{r} / \mathrm{min})$, enzyme activity was measured. In addition, 
118 enzyme activity was examined at different temperatures $\left(30,33,37,40\right.$ and $\left.42^{\circ} \mathrm{C}\right)$, various time

119 points $(12,16,20,24,28$ and $32 \mathrm{~h}$ of culture), different initial $\mathrm{pH}(6.2,6.5,6.8,7.1$ and 7.4$)$ and

120 different shaker rotational speeds $(150,200,250$ and $300 \mathrm{r} / \mathrm{min})$. A sterile control flask without

121 bacteria and under identical experimental conditions ran concurrently. Fermentation experiments

122 were carried out in a $5 \mathrm{~L}$ fermenter (B.E. Marubishi, Japan) and a $20 \mathrm{~L}$ fermenter (Zhenjiang East

123 Biotech, PR. China) based on the test tube and shaker flask cultures. We evaluated the effects of a

124 range of crucial operational parameters, including inoculation volume, $10 \%$; ventilation rate, 5

$125 \mathrm{~L} / \mathrm{min}$; rotational speed, $500 \mathrm{r} / \mathrm{min}$; initial temperature, $37^{\circ} \mathrm{C}$; initial $\mathrm{pH}, 6.8-7.2$; and initial

126 dissolved oxygen (DO) value, 99. After fermentation for $8 \mathrm{~h}$, the DO value was reduced to 0 . Once

127 the level of bubbles reached the alarm value, fermentation was terminated. The experiments lasted

128 approximately 20 hours. All experiments were conducted in triplicate and the average values were

129 reported.

1302.4 Immobilization of alpha-glucosidase on magnetic chitosan microspheres

131 The preparation method for immobilization alpha-glucosidase on magnetic chitosan microspheres

132 was previously described (Denkbaş et al., 2002). Firstly, preparation of magnetic chitosan

133 microspheres: $\mathrm{Nano} \mathrm{Fe}_{3} \mathrm{O}_{4}$ particles and chitosan were added to an acetic acid solution at a specific

134 ratio. After $24 \mathrm{~h}$ of incubation, the mixture was subjected to ultrasonic dispersion for $30 \mathrm{~min}$.

135 Subsequently, $70 \mathrm{~mL}$ of liquid paraffin and $7 \mathrm{~mL}$ of Span- 80 were added to a triangular flask and

136 mixed thoroughly by stirring at $40^{\circ} \mathrm{C}$ for $20 \mathrm{~min}$. The $\mathrm{Fe}_{3} \mathrm{O}_{4}$ particle-containing chitosan solution

137 was then added dropwise to the flask. After agitation for $30 \mathrm{~min}, 5 \mathrm{~mL}$ of $4 \%$ glutaraldehyde

138 solution was added and allowed to react for $1 \mathrm{~h}$. Afterwards, the $\mathrm{pH}$ of the reaction mixture was

139 adjusted to approximately 10.0 with $1 \mathrm{~mol} / \mathrm{L} \mathrm{NaOH}$ solution. The mixture was then heated to 60

$140{ }^{\circ} \mathrm{C}$ and allowed to react for another $2 \mathrm{~h}$. To recover the magnetic chitosan microspheres, the 
141 reaction products were collected using a magnet, washed successively with petroleum ether, 142 acetone and distilled water, and vacuum-dried at $60^{\circ} \mathrm{C}$ (Denkbaş et al., 2002). Secondly, 143 immobilization of alpha-glucosidase on magnetic chitosan microspheres. Eight micrograms of 144 magnetic chitosan microspheres were immersed in $2 \mathrm{~mL}$ of $1.5 \%$ acetic acid solution for $24 \mathrm{~h}$, 145 allowing for the full swelling of the microspheres. Six microliters of $0.1 \mathrm{~mol} / \mathrm{L} \mathrm{NaOH}$ solution 146 was then added to the microspheres. Alpha-glucosidase was dissolved in $0.1 \mathrm{~mol} / \mathrm{L}$ phosphate 147 buffer ( $\mathrm{pH}$ 6.8) to prepare a solution with an enzyme concentration of $6.5 \mathrm{mg} / \mathrm{mL}$. The prepared 148 enzyme solution was then added to the chitosan gel. Enzyme adsorption was achieved by oscillation at $30{ }^{\circ} \mathrm{C}$ and $150 \mathrm{r} / \mathrm{min}$ for $1 \mathrm{~h}$. Subsequently, crosslinking of the enzyme was conducted by addition of $2 \mathrm{~mL}$ of $1 \%$ glutaraldehyde solution and oscillation at a constant speed of $150 \mathrm{r} / \mathrm{min}$ for $1 \mathrm{~h}$ at $60^{\circ} \mathrm{C}$. The chitosan gel was then washed with $0.1 \mathrm{~mol} / \mathrm{L}$ phosphate buffer $(\mathrm{pH} 6.8)$ until no free enzyme could be detected by the ninhydrin method. The immobilized alpha-glucosidase was collected using a magnet, and the activity of the immobilized enzyme was determined. Lastly, the activity recovery rate of the immobilized enzyme was calculated as follows: activity recovery rate of the immobilized enzyme $(\%)=\mathrm{X} 1 / \mathrm{X} 2$, where $\mathrm{X} 1$ was the total activity of the immobilized enzyme $(\mathrm{m} \mathrm{mol} / \mathrm{g})$ and $\mathrm{X} 2$ was the total activity of the added free enzyme $(\mathrm{m} \mathrm{mol} / \mathrm{g})$. Protein detection by the ninhydrin colorimetric method has been described previously (Hung et al., 2005). 2.5 The effects of immobilization conditions on the efficiency of alpha-glucosidase immobilization Chitosan and $\mathrm{Fe}_{3} \mathrm{O}_{4}$ were added to a $1 \%$ acetic acid solution at ratios of 1:0.5, 1:1, 1:2, 1:3 and 1:4 successively. The mixtures could sit for $24 \mathrm{~h}$ and then subjected to ultrasonic dispersion for 30 min. The $\mathrm{pH}$ of the resulting chitosan gel systems was adjusted to approximately $10.0 \mathrm{with} 1 \mathrm{~mol} / \mathrm{L}$ $\mathrm{NaOH}$, and the states of the systems were examined. Subsequently, 0.5, 1.0, 1.5, 2.0, 2.5, 3.0 and $4.0 \mathrm{~mL}$ of enzyme solution (enzyme concentration: $6.5 \mathrm{mg} / \mathrm{mL}$ ) were added to the chitosan gel 
164 solutions successively, and the activity of the immobilized enzyme was determined. Alpha165 glucosidase was then added to the chitosan gel solutions at a certain concentration and allowed to 166 absorb for $0.5,1,1.5,2$, and $2.5 \mathrm{~h}$. The effects of various concentrations of glutaraldehyde $(1,2$, 1673,4 and $5 \%$ ) on enzyme immobilization were determined. Crosslinking of the adsorbed enzyme

168

169

170

171

172

173

was then carried out for a certain length of time at $35,40,45,50$ and $55^{\circ} \mathrm{C}$ in the presence of $4 \%$ glutaraldehyde. In addition, the crosslinking duration was varied $(0.5,1.0,1.5,2.0$ and $2.5 \mathrm{~h})$. The activity of the immobilized enzyme was measured under each condition.

2.6 Optimization of the transglycosidation process

An appropriate dextrose equivalent (DE) value was used as an indicator (in the present study, a DE value of 12 was used). The DE value was determined using the iodometric method (Lin et al., 2012). The effects of various factors on the process of liquefaction were individually investigated. Corn starch was weighed, and the desired amounts of corn starch were added to distilled water, creating aqueous slurries with $15 \%, 20 \%, 25 \%, 30 \%$ and $35 \%$ starch. The starch slurries were preheated in a $95{ }^{\circ} \mathrm{C}$ water bath for $5 \mathrm{~min}$. Subsequently, thermostable alpha-amylase $(15 \mathrm{U} / \mathrm{g})$ was added to the starch slurries. After a 10-min liquefaction, the alpha-amylase was inactivated by increasing the acidity and raising the temperature. The effect of substrate (starch) concentration on the DE value of the liquefied solution was examined. The effect of the dosage of thermostable alpha-amylase on the DE value of the liquefied solution was determined using the following procedure: The concentration of the starch slurry was adjusted to the optimum based on the result of (1). The starch slurries were then preheated in a water bath at $95^{\circ} \mathrm{C}$ for $5 \mathrm{~min}$. Subsequently, various doses of thermostable alpha-amylase $(10 \mathrm{U} / \mathrm{g}, 15 \mathrm{U} / \mathrm{g}, 20 \mathrm{U} / \mathrm{g}, 25 \mathrm{U} / \mathrm{g}$ and $30 \mathrm{U} / \mathrm{g}) \mathrm{were}$ added to the starch slurries. After a 10-min liquefaction, the alpha-amylase was inactivated by increasing the acidity and raising the temperature. The effect of the dosage of thermostable alpha- 
187 amylase on the DE value of the liquefied solution was examined. The effect of liquefaction time

188 on the DE value of the liquefied solution was determined using the following method: The

189

190

191

192

193

194

195

196

197

198

199

200

201

202

203

204

205

206

207

208

209

concentration of the starch slurry was adjusted to the optimum based on the result of (1). The starch

slurries were then preheated for $5 \mathrm{~min}$ in a $95{ }^{\circ} \mathrm{C}$ water bath. Subsequently, the optimal dose of thermostable alpha-amylase, which was determined in (2), was added to the starch slurries. After liquefaction for various lengths of time $(8 \mathrm{~min}, 10 \mathrm{~min}, 12 \mathrm{~min}, 14 \mathrm{~min}, 16 \mathrm{~min}, 18 \mathrm{~min}$ and 20 $\min$ ), the alpha-amylase was inactivated by increasing the acidity and raising the temperature. The effect of liquefaction time was then examined. Based on the results of the single-factor experiments, the experimental factors and levels of the liquefaction process were determined through orthogonal analysis (Table 1). The main factors affecting the saccharification and transglucosidation process included the following: glucoamylase dosage, saccharification time, dosage of alpha-transglucosidase (purchased from Amano Enzyme Inc., Japan or made in our laboratory) and duration of the transglucosidation process. The isomaltose content was employed as an indicator and was determined by paper chromatography (Zhang et al., 2011). The effects of various factors on the saccharification and transglucosidation processes were determined individually.

\subsection{Preparation of IMO}

IMO preparation was performed according to the reported method (Goulas et al., 2004). (1) The liquefaction conditions were as follows: corn starch slurry concentration, $20 \%$; dosage of thermostable alpha-amylase, $15 \mathrm{U} / \mathrm{g}$; and liquefaction time, $10 \mathrm{~min}$. (2) The saccharification and transglucosidation conditions were as follows: glucoamylase dosage, $250 \mathrm{U} / \mathrm{g}$; saccharification time, $4.5 \mathrm{~h}$; dosage of transglucosidase, $1 \mathrm{U} / \mathrm{g}$; and the duration of the transglucosidation process, $42 \mathrm{~h}$. 


\section{$210 \quad 2.8$ Analytical procedures}

211 Determination of biomass: One milliliter of the fermentation broth was collected and properly

212 diluted. The absorbance of the fermentation broth at A600 nm was determined, which represented

213 the bacterial density (Suzuki et al., 1984). The enzymatic activity of alpha-glucosidase was

214 measured using a method described previously ( $\mathrm{Wu}$ et al., 2010). The method employed to

215 determine the DE value (the amount of reducing sugars) has been described previously.

216

$$
\mathrm{DE}(\mathrm{G}, \%)=\frac{\mathrm{c}\left(\mathrm{V}_{1}-\mathrm{V}_{2}\right) \times 0.09}{\mathrm{~W} \times \frac{10}{200}} \times 100
$$

where $\mathrm{c}$ is the molar concentration of the sodium thiosulfate standard solution $(\mathrm{mol} / \mathrm{L}), \mathrm{V}_{1}$ is the volume of the sodium thiosulfate standard solution consumed by the blank $(\mathrm{mL}), \mathrm{V}_{2}$ is the volume of the sodium thiosulfate standard solution consumed by the sample $(\mathrm{mL}), \mathrm{W}$ is the mass of fermented sugar $(\mathrm{g})$, and 0.09 represents the number of grams of glucose that was equivalent to 1 $\mathrm{mL}$ of $1 \mathrm{~mol} / \mathrm{L}$ iodine standard solution. Qualitative analysis of the isomaltose content via paper chromatography was performed using the following developing agent: n-butanol: pyridine: water $=6: 4: 3$. The chromogenic reagent (aniline-diphenylamine-phosphoric acid) was prepared by dissolving $4 \mathrm{~g}$ of diphenylamine, $4 \mathrm{~mL}$ of aniline and $20 \mathrm{~mL}$ of $85 \%$ phosphoric acid in $200 \mathrm{~mL}$ of acetone. The prepared IMO syrup was spotted onto chromatography paper and exposed to the developing agent for $4 \mathrm{~h}$. The chromatography paper was removed, dried and then exposed to the developing agent again. This step was repeated 3 times (approximately a total of $12 \mathrm{~h}$ of development). Subsequently, the chromatography paper was naturally dried, sprayed with chromogenic agent and heated at $70-80{ }^{\circ} \mathrm{C}$ for $10 \mathrm{~min}$. The IMO content was preliminarily determined based on the size (diameter) of the developed spots. A high-performance liquid chromatographic (HPLC) method for IMO measurements was based on reported methods 
232 (Vinogradov and Bock, 1998). A Waters Alliance 2695 liquid chromatography unit equipped with

233 a 1515 pump, 717 plus autosampler, a reversed-phase C18 column $(250 \times 4.6 \mathrm{~mm}, 5 \mu \mathrm{m})$ and a

234 Waters 2996 UV detector was used (Waters Co., Milford, CT). The mobile phase was prepared by 235 adding $270 \mathrm{~mL}$ of purified water to $730 \mathrm{~mL}$ of acetonitrile, and then filtered under vacuum through 236 a $0.45-\mu \mathrm{m}$ filter. The HPLC was performed at a flow rate of $1.3 \mathrm{~mL} / \mathrm{min}$ and an injection volume 237 of $20 \mu \mathrm{L}$.

\section{3. Results and discussion}

3.1 The effect of environmental parameters on enzyme production by G. stearothermophilus U2

The effects of different carbon sources on the production of enzyme were investigated using $G$. stearothermophilus U2. Among the carbohydrates tested, the highest production of a-glucosidase was achieved by glucose as the carbon source (Fig. 2a). Furthermore, both starch and maltose were capable of serving as effective carbon sources and promoting the synthesis of alpha-glucosidase. In addition, the ability of the enzyme to act on starch and maltose was induced when the two types of sugar were present. In contrast, lactose and sucrose were not conducive to enzyme production. The effects of different nitrogen sources on enzyme production by G. stearothermophilus U2 were examined (Fig. 2b). Various nitrogen sources $(0.5 \mathrm{~g} / \mathrm{L})$ were added to basic potato medium $(20 \%$ potato, Control). Bacterial strain U2 was then inoculated into the medium. After culture of the bacteria for $24 \mathrm{~h}$, at $\mathrm{pH} 7.0$ and $37{ }^{\circ} \mathrm{C}$ with shaking (shaker rotational speed, $200 \mathrm{r} / \mathrm{min}$ ), enzyme activity was examined. When beef extract, peptone and yeast powder were selected as the nitrogen source, the synthesis of alpha-glucosidase was promoted. Therefore, beef extract, peptone and yeast powder are ideal nitrogen sources for the fermentation medium. The effects of various inorganic salts on enzyme production by $G$. stearothermophilus U2 were also examined. Different 
$255 \mathrm{mmol} / \mathrm{L}$. Enzyme activity in the inorganic salt-free system was assigned a $100 \%$ value. The

256 promoted enzyme production was $\mathrm{MgCl}_{2}, \mathrm{~K}_{2} \mathrm{HPO}_{4}, \mathrm{CaCl}_{2}$ and $\mathrm{MnCl}_{2}$, relative activity of 257 accounting for $118.0 \%, 115 \%, 112 \%, 108 \%$ and $31.01 \%$, respectively. Whereas $\mathrm{CoCl}_{2}, \mathrm{FeCl}_{2}$, $258 \mathrm{ZnCl}_{2}$ and $\mathrm{CuCl}_{2}$ each comprised only $86 \%, 45 \%, 45 \%, 8 \%$, respectively. Based on the above 259 experimental results, starch, peptone, beef extract, yeast powder, $\mathrm{MgCl}_{2}$ and $\mathrm{K}_{2} \mathrm{HPO}_{4}$ were 260 selected as the components of the optimized fermentation medium. To determine the effect of 261 fermentation temperature on enzyme production by G. stearothermophilus U2, fermentation was 262 carried out for $24 \mathrm{~h}$, at $\mathrm{pH} 7.0$, a rotational speed of $200 \mathrm{r} / \mathrm{min}$ and at varying temperatures, and enzyme activities were measured. As shown in Fig. 2c, enzyme activity was very low at $30^{\circ} \mathrm{C}$ but 264 rather high at $42{ }^{\circ} \mathrm{C}$. Therefore, the fermentation temperature was controlled at $37{ }^{\circ} \mathrm{C}$. To 265 determine the highest temperature of the enzyme, fermentation temperature continuing increased up to $55^{\circ} \mathrm{C}$, enzyme activity is kept half as much as $37{ }^{\circ} \mathrm{C}$. The thermal stability of alpha-

267 268

269

270

271

272

273

274

275

276 277 transglucosidase was further tested during the long incubation period. The enzyme was thermostable and no loss in activity was found below $37^{\circ} \mathrm{C}$, but it was inactivated at $65^{\circ} \mathrm{C}$ or more and completely lost its activity at $80^{\circ} \mathrm{C}$. Thus, alpha-transglucosidase produced by $G$. stearothermophilus U2 possess heat-resistant properties, which is very important role as thermal stability to produce IMOs in food industry. To determine the effect of culture time on enzyme production by G. stearothermophilus $\mathrm{U} 2$, the activity of the enzyme produced was measured after culturing the bacteria for varying lengths of time (Fig. 2d). The results showed that enzyme activity was the highest when the culture time was $20 \mathrm{~h}$. To determine the effect of the initial $\mathrm{pH}$ on enzyme production by $G$. stearothermophilus $\mathrm{U} 2$, fermentation was carried out for $20 \mathrm{~h}$ at $37{ }^{\circ} \mathrm{C}$ and different $\mathrm{pH}$ levels, and enzyme activity was measured (Fig. 2e). The results showed that the optimal initial $\mathrm{pH}$ value was 6.8. Finally, the effect of shaker rotational speed on enzyme 
278 production by $G$. stearothermophilus U2 was examined. Enzyme production is an oxygen279 consuming fermentation process. During fermentation, the ventilation volume was adjusted by 280 changing the shaker rotational speed. After $20 \mathrm{~h}$ of fermentation, enzyme activity was measured 281 (Fig. 2f). It was found that low rotational speeds and small ventilation volumes were not conducive

282

to bacterial growth. However, premature autolysis of bacteria would occur if the rotational speed was too high, which led to decreased biomass and reduced enzyme activity. Therefore, the optimal rotational speed was $200 \mathrm{r} / \mathrm{min}$.

\subsection{Fermentation experiments using $5 \mathrm{~L}$ and $20 \mathrm{~L}$ fermenters}

Fermentation experiments were carried out in $5 \mathrm{~L}$ fermenters based on test tube and shaker flask cultures. The medium used in the experiments was an optimized liquid fermentation medium. The fermentation conditions were also optimized: $10 \%$ inoculum, $\mathrm{pH} 6.8,37^{\circ} \mathrm{C}$ and $20 \mathrm{~h}$ of incubation. The bacteria cultured in $10 \mathrm{ml}$ test-tube $(0.71 \mathrm{U} / \mathrm{mL})$ were 1.2 times higher than those of the unoptimized cultivation $(0.60 \mathrm{U} / \mathrm{mL})$. The bacteria cultured in $10 \mathrm{ml}$ test-tube were inoculated into $250 \mathrm{ml}$ shake-flask and placed on a shaker. After culture for $20 \mathrm{~h}$ at $37^{\circ} \mathrm{C}$ with vigorous stirring (200 r/min), enzyme activity was evaluated. Subsequently, G. stearothermophilus that had been cultured for $20 \mathrm{~h}$ in $250 \mathrm{ml}$ shake-flask were transferred into the $5 \mathrm{~L}$ fermentation tank. After $20 \mathrm{~h}$ of culture (rotational speed, $200 \mathrm{r} / \mathrm{min}$; ventilation volume, $1.7 ; 37^{\circ} \mathrm{C}$ ), enzyme activity was measured. Whereas $250 \mathrm{ml}$ shake flask cultivation and $5 \mathrm{~L}$ fermentation tank comprised $1.42 \mathrm{U} / \mathrm{mL}$ and $2.62 \mathrm{U} / \mathrm{mL}$, respectively. The bacteria cultured in $5 \mathrm{~L}$ fermentation tank were 4.4 times higher than those of the unoptimized cultivation. At the completion of the 20 L-scale fermentation experiments, bacteria cultures were stored at $4{ }^{\circ} \mathrm{C}$ for future assays. The bacteria were centrifuged in batches (centrifugation conditions: 10,000 r/min for $20 \mathrm{~min}$ ). The resulting pellets were collected with acetic acid-sodium acetate buffer ( $\mathrm{pH}$ 6.0) and phosphate buffer ( $\mathrm{pH}$ 6.8) and were 
301 stored at $-18{ }^{\circ} \mathrm{C}$. Enzyme production by ten batches of fermentation reaction were observed.

302 Enzyme activity of ten batches from 15.44 to $48.25 \mathrm{U} / \mathrm{mL}$, with weight of bacterial cells from 2.0

303

304

305

306

307

308

309

310

311

312

313

314

315

316

317

318

319

320

321

322

323

to $4.0 \mathrm{~g}$, which was harvested from $130.30 \mathrm{~L}$ of bacterial culture and $456.05 \mathrm{~g}$ of weight of the pellet.

3.3 Immobilization of alpha-glucosidase on magnetic chitosan microspheres

Determination of the ratio of chitosan to $\mathrm{Fe}_{3} \mathrm{O}_{4}$ : Various chitosan/ $\mathrm{Fe}_{3} \mathrm{O}_{4}$ ratios and the resulting states of the system were observed. With increasing $\mathrm{Fe}_{3} \mathrm{O}_{4}$, increasing amounts of free $\mathrm{Fe}_{3} \mathrm{O}_{4}$ appeared in the system. No free chitosan or $\mathrm{Fe}_{3} \mathrm{O}_{4}$ was detected in the system when the chitosan $/ \mathrm{Fe}_{3} \mathrm{O}_{4}$ ratio was $1: 1$. Therefore, the ratio of chitosan to $\mathrm{Fe}_{3} \mathrm{O}_{4}$ was set to $1: 1$, which ensured the highest material efficiency. There is a certain limit to the amount of alpha-glucosidase that can be immobilized by the given chitosan gel. To immobilize the maximum amount of alphaglucosidase without wasting enzyme, the effect of enzyme dosage on enzyme immobilization was investigated. The results are shown in Fig. 3(a). When the enzyme dosage was relatively low, the activity of the immobilized enzyme rose rapidly as the enzyme dosage increased. After the enzyme dosage reached $3 \mathrm{~mL}$, the magnitude of the increase in the activity of the immobilized enzyme was reduced significantly, and the enzyme activity recovery rate decreased sharply. Therefore, $3 \mathrm{~mL}$ appeared to be an appropriate enzyme dose. Under such condition, the activity of the immobilized enzyme was $282.18 \mathrm{mmol} / \mathrm{g}$, and the enzyme activity recovery rate was $64.87 \%$. The effect of adsorption time on enzyme immobilization was examined, and the results are shown in Fig. 3 (b). A certain concentration of $\alpha$-glucosidase was added to the chitosan gel. The activity of the immobilized enzyme reached the maximum when the adsorption time was $2 \mathrm{~h}$. Therefore, $2 \mathrm{~h}$ of adsorption was appropriate for enzyme immobilization. The effects of crosslinking temperature on enzyme immobilization are shown in Fig. 3(c). As the crosslinking temperature rose, the activity 
324 of the immobilized enzyme increased accordingly. The activity of the immobilized enzyme

325 reached the maximum when the crosslinking temperature was $50{ }^{\circ} \mathrm{C}$. However, enzyme activity

326 started to decline when the crosslinking temperature was further increased. Therefore, crosslinking

327 at $50{ }^{\circ} \mathrm{C}$ was appropriate for enzyme immobilization. The effects of glutaraldehyde concentration

328 on enzyme immobilization are shown in Fig. 3 (d). Glutaraldehyde was added to the chitosan gel

329 that had adsorbed a certain amount of alpha-glucosidase to induce crosslinking. The activity of the

330 immobilized enzyme reached the maximum when the glutaraldehyde concentration was $4 \%$.

331 However, enzyme activity declined rapidly as the glutaraldehyde concentration was further

332 increased. It is likely that the enzyme was inactivated when the glutaraldehyde concentration 333 exceeded a certain threshold. Therefore, a glutaraldehyde concentration of $4 \%$ was appropriate

334 for enzyme immobilization. The effects of crosslinking time on enzyme immobilization are shown

335 in Fig. 3 (e). Under the present experimental conditions, the activity of the immobilized enzyme

336 reached the maximum when the crosslinking time was $1.5 \mathrm{~h}$. Enzyme activity was then decreased

337 as the crosslinking time was further prolonged. The decrease in enzyme activity might be due to

338 the denaturation of the enzyme induced by over-crosslinking of the enzyme with glutaraldehyde.

339 Therefore, a crosslinking time of $1.5 \mathrm{~h}$ was appropriate for enzyme immobilization.

3403.4 Preparation, detection and comparison of IMOs

341 3.4.1 Optimization of the liquefaction process

342 The effect of substrate concentration on the DE value of the liquefied solution: Substrate 343 concentration is one of the key factors affecting the DE value of the liquefied solution. In addition, 344 substrate concentration indirectly affects the degree of saccharification. As shown in Fig. 4 (a), the 345 DE value of the liquefied solution rose as the corn starch concentration increased. When the corn 346 starch concentration was $15 \%$, the DE value of the liquefied solution was $10.54 \%$. The DE value 
347 of the liquefied solution increased to $12.04 \%$ when the corn starch concentration increased to 20

$348 \%$. The corn starch slurry would become over-thickened if the concentration of corn starch was

349 further increased, leading to incomplete liquefaction and the appearance of clot. Therefore, the 350 corn starch slurry concentration should be controlled at approximately $20 \%$ when liquefying. The 351 effect of enzyme dosage on the DE value of the liquefied solution: As shown in Fig. 4 (b), the DE 352 value showed a constant upward trend as the dosage of thermostable alpha-amylase increased. The 353 DE value of the liquefied solution reached $12.25 \%$ when the dosage of the liquefying enzyme was $35420 \mathrm{U} / \mathrm{g}$. It may be seen that the highest conversion of corn starch (DE value 14.2\%) was achieved 355 with $30 \mathrm{U} / \mathrm{g}$ of adding amount of alpha-amylase. However, an incomplete liquefaction and the 356 appearance of clot were obtained in more than $12.00 \%$ of the DE value of the liquefied solution. Obviously, the desired conversions could be achieved with lower enzyme concentrations. Therefore, indicating that the lower amount of alpha-amylase is sufficient for the effective conversion of the substrate. The effect of liquefaction time on the DE value of the liquefied solution: As shown in Fig. 4(c), the DE value displayed a constant upward trend as the liquefaction time increased. The DE value of the liquefied solution reached $11.96 \%$ (a desired DE value for the liquefied solution) after 12 min of reaction. It may be seen from Fig. 4(c) that DE value of 14.6 $\%$ is reached after 16 min, while a DE value of $11.96 \%$ could be obtained with 12 min of reaction. However, to our opinion, improving of the DE value is not economically justified because of the incomplete liquefaction. In addition, the longer exposure of the enzyme to high temperatures, which are needed for gelatinization of the corn starch granules and for achieving a good susceptibility to enzyme action, could lead to slight enzyme deactivation (Mojović et al., 2006). Therefore, it was concluded that the optimal liquefaction time was $12 \mathrm{~min}$. Orthogonal tests of the

369 liquefaction process have been investigated according to the design shown in Table 2. Corn starch 
370 was used as the raw material and subjected to liquefaction by thermostable alpha-amylase. After

371 the alpha-amylase was inactivated, the DE value of the liquefied corn starch was determined. The

372 DE value of the liquefied solution served as an index. The effects of corn starch slurry 373 concentration, liquefying enzyme dosage and liquefaction time on the DE value were investigated

374

375

376

377

378

379

380 under specific liquefaction conditions ( $\mathrm{pH} 6.5$ and water bath temperature of $95^{\circ} \mathrm{C}$ ). The results of the orthogonal test (shown in Table 2) were subjected to range analysis using SPSS 16.0 software. The DE value was used as an indicator. As shown in Table 3, the most important experimental factor influencing corn starch liquefaction was $\mathrm{A}$, followed by $\mathrm{C}$ and then $\mathrm{B}$ (i.e., $\mathrm{A}$ $>\mathrm{C}>\mathrm{B}$ ). The optimal collocation of the factors was A2 $>\mathrm{C} 1>\mathrm{B} 1$. Namely, the corn starch slurry concentration was $20 \%$, the dosage of thermostable alpha-amylase was $15 \mathrm{U} / \mathrm{g}$, and the liquefaction time was 10 min. Confirmatory testing was conducted based on the collocation of $\mathrm{A}_{2} \mathrm{C}_{1} \mathrm{~B}_{1}$, and the $\mathrm{DE}$ value of the liquefied solution was $12.05 \% . \mathrm{A}_{1} \mathrm{~B}_{3} \mathrm{C}_{3}$-based confirmatory testing yielded a DE value of $12.45 \%$. Intuitive analysis suggests that subsequent saccharification should not be pursued. Therefore, the optimal level of the factors was $A_{2} C_{1} B_{1}$.

\subsubsection{Optimization of the saccharification and transglucosidation processes}

The effect of the dosage of glucoamylase on isomaltose content: IMOs were prepared using different doses of glucoamylase and then subjected to paper chromatography. The results are shown in Fig. 5 (a). The IMO content was highest when $250 \mathrm{U} / \mathrm{g}$ glucoamylase was used. The effect of saccharification time on isomaltose content: The experimental results are shown in Fig. 5(b). The highest amount of IMO was produced after $4.5 \mathrm{~h}$ of saccharification. The effect of the dosage of alpha-transglucosidase on isomaltose content: The experimental results showed that the IMO content was highest when the dose of transglucosidase was $1.00 \mathrm{U} / \mathrm{g}$. The effect of the duration of transglucosidation reaction on isomaltose content: The experimental results showed 
393 that the IMO content was highest when the duration of transglucosidation was $42 \mathrm{~h}$. In the present

394 study, the IMO syrups produced using 3 different transglucosidases were subjected to HPLC 395 analysis. The HPLC results are shown in Fig. 6 (A), (B) and (C). The activities of the 396 transglucosidases and the enzymatic conversion rates are shown in Table 4. The enzymatic activity 397 of the transglucosidase made in this study was lower than the activity of the commercially available 398 transglucosidases (the transglucosidases purchased from Amano Enzyme Inc., Japan and Shanghai 399 Co., Ltd.). The transglucosidase made in our laboratory exhibited a transglucosidation rate of 6.69 $400 \%$, which was also lower compared with the transglucosidases purchased from Amano Enzyme Inc., Japan (14.85\%) and Shanghai Co., Ltd (24.44 \%). Moreover, we found that glucose, maltose,

402 403 404 405 406 isomaltose, maltotriose, panose and pentasaccharide were identified by the HPLC patterns, but except that of isomaltotriose and tetrasaccharide. Interestingly, maltotriose was mainly contains in IMO syrup that was produced using the transglucosidase purchased from Japan and Shanghai. These provide a reasonable explanation as to why the transglucosidation rate was lowest in our IMO syrup. In addition, the IMO prepared in our laboratory and the commercially available IMOs were analyzed by HPLC. The results are shown in Fig. 7 (A), (B) and (C). The contents of the oligosaccharides are shown in Table 5. The content of the oligosaccharides in the lab-made IMOs was $41.74 \%$, which is lower compared with the IMO purchased from Shandong Co., Ltd. (44.84 \%) but it is higher than Henan Food-additive Co., Ltd (36.78 \%). Moreover, the glucose content was $9.81 \%$ for this study, $0.0 \%$ for Shandong Co., Ltd. and $3.44 \%$ for Henan Co., Ltd.. One the hand, the results might be related to the fact that the saccharides were unpurified. One the other hand, How to decease glucose content and to increase content of the oligosaccharides will be an important core in the IMO industrial.

\section{Conclusion}


416 The optimized the conditions for biotransformation of starch into isomaltooligosaccharides using

417 thermostable alpha-glucosidase from G. stearothermophilus U2 has been investigated. Under the 418 optimal conditions, 5-20 L batch fermentation was explored in this work. The alpha-glucosidase 419 activity was strongly inhibited by $\mathrm{Mn}^{2+}, \mathrm{Co}^{2+}, \mathrm{Fe}^{2+}, \mathrm{Zn}^{2+}$ and $\mathrm{Cu}^{2+}$. IMOs were then prepared using 420 chitosan membrane-immobilized alpha-glucosidase, beta-amylase, pullulanase, fungal alpha421 amylase and starch as substrate. The mixed syrup that contained IMOs was evaluated and analyzed 422 by thin-layer chromatography and high-performance liquid chromatography (HPLC). In addition, 423 small-scale preparation of IMOs was performed. The enzyme preparation was used in IMO 424 production, resulting in an oligosaccharide content of $41.74 \%$ and the glucose content was $9.81 \%$. 425 These results are a strong indication that fundamental knowledge of alpha-transglucosidase426 producing $G$. stearothermophilus as a potential application technique can be successfully used to 427 prepare industrial IMOs. 
429

430

431

432

433

434

435

436

437

438

439

440

441

442

443

444

445

446

447

448

449

450

451

\section{Reference}

Benayad, S., Adam, E., Soulet, S., Bombarda, I., Debitus, C., and Teai, T. (2016). Vaccinium cereum leaves, Tahitian berry, a common endemic plant with alpha-glucosidase inhibitory activity. Planta Med 81, S1-S381.

Chen, J., and Xie, L. (2008). Solid fermentation optimization of Monascus ruber van tieghem for producing a-glucosidase. China Brewing 18, 21.

Chockchaisawasdee, S., and Poosaran, N. (2013). Production of isomaltooligosaccharides from banana flour. J Sci Food Agric 93, 180-186.

Denkbaş, E.B., Kiliçay, E., Birlikseven, C., and Öztürk, E. (2002). Magnetic chitosan microspheres: preparation and characterization. Reactive and Functional Polymers 50, $225-232$.

Giles-Rivas, D.E., Aguilar-Guadarrama, B., Castillo-Espana, P., Ramirez-Avila, G., and EstradaSoto, S.E. (2016). alpha-Glucosidase inhibitory activity of extracts from Cordia morelosana. Planta Med 81, S1-S381.

Goulas, A.K., Cooper, J.M., Grandison, A.S., and Rastall, R.A. (2004). Synthesis of isomaltooligosaccharides and oligodextrans in a recycle membrane bioreactor by the combined use of dextransucrase and dextranase. Biotechnol Bioeng 88, 778-787.

Gutierrez-Alonso, P., Gimeno-Perez, M., Ramirez-Escudero, M., Plou, F.J., Sanz-Aparicio, J., and Fernandez-Lobato, M. (2016). Molecular characterization and heterologous expression of a Xanthophyllomyces dendrorhous alpha-glucosidase with potential for prebiotics production. Appl Microbiol Biotechnol 100, 3125-3135.

Hatano, A., Kanno, Y., Kondo, Y., Sunaga, Y., Umezawa, H., Okada, M., Yamada, H., Iwaki, R., Kato, A., and Fukui, K. (2017). Synthesis and characterization of novel, conjugated, 
452

453

454

455

456

457

458

459

460

461

462

463

464

465

466

467

468

469

470

471

472

473

474

fluorescent DNJ derivatives for alpha-glucosidase recognition. Bioorg Med Chem 25, 773778.

Hirschhorn, R., Huie, M.L., and Kasper, J.S. (2002). Computer assisted cloning of human neutral alpha-glucosidase C (GANC): a new paralog in the glycosyl hydrolase gene family 31 . Proc Natl Acad Sci U S A 99, 13642-13646.

Hossain, T.J., Harada, Y., Hirayama, H., Tomotake, H., Seko, A., and Suzuki, T. (2016). Structural Analysis of Free N-Glycans in alpha-Glucosidase Mutants of Saccharomyces cerevisiae: Lack of the Evidence for the Occurrence of Catabolic alpha-Glucosidase Acting on the NGlycans. PLoS One 11, e0151891.

Hung, V.S., Hatada, Y., Goda, S., Lu, J., Hidaka, Y., Li, Z., Akita, M., Ohta, Y., Watanabe, K., Matsui, H., Ito, S., and Horikoshi, K. (2005). alpha-Glucosidase from a strain of deep-sea Geobacillus: a potential enzyme for the biosynthesis of complex carbohydrates. Appl Microbiol Biotechnol 68, 757-765.

Johnson, O.O., Zhao, M., Gunn, J., Santarsiero, B.D., Yin, Z.Q., Ayoola, G.A., Coker, H., and Che, C.T. (2016). alpha-Glucosidase inhibitory prenylated anthranols from Harungana madagascariensis. Planta Med 81, S1-S381.

Kaneko, T., Matsukubo, T., Yatake, T., Muramatsu, Y., and Takaesu, Y. (1995). Evaluation of acidogenicity of commercial isomaltooligosaccharides mixture and its hydrogenated derivative by measurement of $\mathrm{pH}$ response under human dental plaque. Biosci Biotechnol Biochem 59, 372-377.

Khang, P.V., Phuong, D.M., and Ma, L. (2016). New steroids from Anemarrhena asphodeloides rhizome and their alpha-glucosidase inhibitory activity. J Asian Nat Prod Res, 1-6.

Kim, M.J., Kim, Y.H., Song, G.S., Suzuki, Y., and Kim, M.K. (2016). Enzymatic 
475

476

477

478

479

480

481

482

483

484

485

486

487

488

489

490

491

492

493

494

495

496

497

transglycosylation of ginsenoside $\mathrm{Rg} 1$ by rice seed alpha-glucosidase. Biosci Biotechnol Biochem 80, 318-328.

Lambert, R., and Zilliken, F. (1965). Novel growth factors for Lactobacillus bifidus var pennsylvanicus. Arch Biochem Biophys 110, 544-550.

Li, W., Xue, Y., Li, J., Yuan, J., Wang, X., Fang, W., Fang, Z., and Xiao, Y. (2016). A coldadapted and glucose-stimulated type II alpha-glucosidase from a deep-sea bacterium Pseudoalteromonas sp. K8. Biotechnol Lett 38, 345-349.

Lin, A.H., Lee, B.H., Nichols, B.L., Quezada-Calvillo, R., Rose, D.R., Naim, H.Y., and Hamaker, B.R. (2012). Starch source influences dietary glucose generation at the mucosal alphaglucosidase level. J Biol Chem 287, 36917-36921.

Liu, X., Wu, D., Wu, J., and Chen, J. (2013). Optimization of the production of Aspergillus niger alpha-glucosidase expressed in Pichia pastoris. World J Microbiol Biotechnol 29, 533-540.

Madariaga-Mazon, A., Rebollar-Ramos, D., Verastegui-Omana, B., Flores-Bocanegra, L., and Mata, R. (2016). alpha-Glucosidase inhibitors from Malbranchea flavorosea. Planta Med 81, S1-S381.

Maina, N.H., Virkki, L., Pynnonen, H., Maaheimo, H., and Tenkanen, M. (2011). Structural analysis of enzyme-resistant isomaltooligosaccharides reveals the elongation of alpha-(1->3)-linked branches in Weissella confusa dextran. Biomacromolecules 12, 409-418.

Masuda, Y., Okuyama, M., Iizuka, T., Nakai, H., Saburi, W., Fukukawa, T., Maneesan, J., Tagami, T., Naraoka, T., Mori, H., and Kimura, A. (2016). Purification and characterization of a chloride ion-dependent alpha-glucosidase from the midgut gland of Japanese scallop (Patinopecten yessoensis). Biosci Biotechnol Biochem 80, 479-485.

Mohamed Sham Shihabudeen, H., Hansi Priscilla, D., and Thirumurugan, K. (2011). Cinnamon 
498

499

500

501

502

503

504

505

506

507

508

509

510

511

512

513

514

515

516

517

518

519

520

extract inhibits alpha-glucosidase activity and dampens postprandial glucose excursion in diabetic rats. Nutr Metab (Lond) 8, 46.

Mojović, L., Nikolić, S., Rakin, M., Vukasinović, M. 2006. Production of bioethanol from corn meal hydrolyzates. Fuel, 85(12-13), 1750-1755.

Nawaz, M.A., Bibi, Z., Aman, A., Zohra, R.R., and Qader, S.A. (2014). Enhanced production of maltase (alpha-glucosidase) from newly isolated strain of Bacillus licheniformis KIBGEIB4. Pak J Pharm Sci 27, 1437-1442.

Nawaz, M.A., Bibi, Z., Karim, A., Rehman, H.U., Jamal, M., Jan, T., Aman, A., and Qader, S.A. (2016). Production of alpha-1,4-glucosidase from Bacillus licheniformis KIBGE-IB4 by utilizing sweet potato peel. Environ Sci Pollut Res Int 24, 4058-4066.

Park, J.E., Park, S.H., Woo, J.Y., Hwang, H.S., Cha, J., and Lee, H. (2013). Enzymatic properties of a thermostable alpha-glucosidase from acidothermophilic crenarchaeon Sulfolobus tokodaii strain 7. J Microbiol Biotechnol 23, 56-63.

Song, K.M., Okuyama, M., Kobayashi, K., Mori, H., and Kimura, A. (2013). Characterization of a glycoside hydrolase family 31 alpha-glucosidase involved in starch utilization in Podospora anserina. Biosci Biotechnol Biochem 77, $2117-2124$.

Suzuki, Y., Shinji, M., and Eto, N. (1984). Assignment of a p-nitrophenyl alpha-Dglucopyranosidase of bacillus stearothermophilus ATCC 12016 to a novel exo-alpha-1, 4glucosidase active for oligomaltosaccharides and alpha-glucans. Biochimica et Biophysica Acta (BBA)-Protein Structure and Molecular Enzymology 787, 281-289.

Vinogradov, E., and Bock, K. (1998). Structural determination of some new oligosaccharides and analysis of the branching pattern of isomaltooligosaccharides from beer. Carbohydr Res 309, 57-64. 
521 Watanabe, S., Kakudo, A., Ohta, M., Mita, K., Fujiyama, K., and Inumaru, S. (2013). Molecular

522 cloning and characterization of the alpha-glucosidase II from Bombyx mori and Spodoptera frugiperda. Insect Biochem Mol Biol 43, 319-327.

Wu, K.Y., Huang, S.H., Ding, S., Zhang, Y.K., Chen, G.G., and Liang, Z.Q. (2010). Expression, purification and characterization of recombinant alpha-glucosidase in Pichia pastoris. Folia Microbiol (Praha) 55, 582-587.

Xiao, J., Westbroek, W., Motabar, O., Lea, W.A., Hu, X., Velayati, A., Zheng, W., Southall, N., Gustafson, A.M., Goldin, E., Sidransky, E., Liu, K., Simeonov, A., Tamargo, R.J., Ribes, A., Matalonga, L., Ferrer, M., and Marugan, J.J. (2012). Discovery of a novel noniminosugar acid alpha glucosidase chaperone series. J Med Chem 55, 7546-7559.

Yan, Q.J., Han, P., Yang, S.Q., and Jiang, Z.Q. (2015). Purification and characterization of a novel alpha-glucosidase from Malbranchea cinnamomea. Biotechnol Lett 37, 1279-1286.

Zhang, Y.K., Li, W., Wu, K.Y., Chen, G.G., and Liang, Z.Q. (2011). Purification and characterization of an intracellular alpha-glucosidase with high transglycosylation activity from A. niger M-1. Prep Biochem Biotechnol 41, 201-217.

Zhou, C., Xue, Y., and Ma, Y. (2015). Evaluation and directed evolution for thermostability improvement of a GH 13 thermostable alpha-glucosidase from Thermus thermophilus TC11. BMC Biotechnol 15, 97. 


\section{Figure Captions}

541 Fig. 1 The flow-process diagram of starch biotransformation into isomaltooligosaccharides using

542 thermostable alpha-glucosidase from Geobacillus stearothermophilus

543 Fig. 2 The effects of various environmental factors on bacterial enzyme production

544 (a) The effects of various carbon sources on enzyme production; (b) the effects of various nitrogen 545 sources on enzyme production; (c) the effects of different temperatures on enzyme production; (d) 546 the effects of different $\mathrm{pH}$ on enzyme production; and (E) the effects of different rotational speeds 547 on enzyme production.

548 Fig. 3 Immobilization of alpha-glucosidase on magnetic chitosan microspheres

549 (a) The effect of enzyme dosage on enzyme immobilization; (b) the effects of adsorption time on 550 enzyme immobilization; (c) the effect of crosslinking temperature on enzyme immobilization; (d) 551 the effect of glutaraldehyde concentration on enzyme immobilization; and (e) the effect of 552 crosslinking time on enzyme immobilization.

553 Fig. 4 Optimization of the liquefaction process

554 (a) The effect of substrate concentration on DE value; (b) the effect of enzyme dosage on DE 555 value; and (c) the effect of liquefaction time on DE value.

556 Fig. 5 The effects of various saccharification conditions on IMO content

557 (a) Paper chromatography results showing the effect of glucoamylase dosage on IMO content.

558 Lanes 1, 2, 3, 4, and 5 represent the different doses of glucoamylase used in the saccharification 559 reaction $(150 \mathrm{U} / \mathrm{g}, 200 \mathrm{U} / \mathrm{g}, 250 \mathrm{U} / \mathrm{g}, 300 \mathrm{U} / \mathrm{g}$ and $350 \mathrm{U} / \mathrm{g}$, respectively).

$560 \mathrm{G}_{1}$, glucose; $\mathrm{G}_{2}$, maltose; $\mathrm{G}_{3}$, maltotriose; $\mathrm{G}_{4}$, maltotetraose.

561 (b) Paper chromatography results showing the effects of saccharification time and 562 transglycosidation process on IMO content. 
$563 \mathrm{G}_{1}$, glucose; $\mathrm{G}_{2}$, maltose; $\mathrm{G}_{3}$, maltotriose; $\mathrm{G}_{4}$, maltotetraose.

564 Lanes 1, 2, 3, 4 and 5 represent various saccharification times $(3.0 \mathrm{~h}, 3.5 \mathrm{~h}, 4.0 \mathrm{~h}, 4.5 \mathrm{~h}$ and $5.0 \mathrm{~h}$, 565 respectively); lanes $6,7,8,9$ and 10 represent various doses of transglucosidase added to the 566 reaction $(0.25 \mathrm{U} / \mathrm{g}, 0.50 \mathrm{U} / \mathrm{g}, 0.75 \mathrm{U} / \mathrm{g}, 1.00 \mathrm{U} / \mathrm{g}$ and $1.25 \mathrm{U} / \mathrm{g}$, respectively); lanes $11,12,13,14$ 567 and 15 represent various transglycosidation times ( 38 h, 40 h, 42 h, $44 \mathrm{~h}$ and 48 h, respectively); 568 lane 16 represents the control (distilled water).

569 Fig. 6 HPLC chromatograms of the IMOs prepared using enzymes from different sources

570 a: glucose; b: maltose; c: isomaltose; d: maltotriose; e: panose; f: isomaltotriose; g: tetrasaccharide; 571 h: pentasaccharide.

572 (A) Chromatogram of the IMO syrup that was produced using the transglucosidase prepared in our 573 laboratory; (B) chromatogram of the IMO syrup that was produced using the transglucosidase 574 purchased from Japan; (C) chromatogram of the IMO syrup that was produced using the 575 transglucosidase purchased from Shanghai Co., Ltd., China.

576 Fig. 7 HPLC chromatograms of the IMOs from different sources

577 a: glucose; b: maltose; c: isomaltose; d: maltotriose; e: panose; f: isomaltotriose; g: tetrasaccharide; 578 h: pentasaccharide.

579 (A) Chromatogram of the IMO syrup prepared in this study; (B) Chromatogram of the IMO 580 produced by Shandong Co., Ltd.; (C) chromatogram of the IMO produced by Henan Co., Ltd., 581 China. 


\section{Table 1 (on next page)}

Factors and levels in orthogonal analysis of the liquefaction process 
1

2

\begin{tabular}{|c|c|c|c|}
\hline \multirow{7}{*}{ Level } & \multicolumn{3}{|c|}{ Factor } \\
\hline & \multicolumn{3}{|c|}{$\mathrm{B}$} \\
\hline & A & & $\mathrm{C}$ \\
\hline & & Dosage of & \\
\hline & Starch slurry & & Liquefaction time \\
\hline &. & liquefying enzyme & 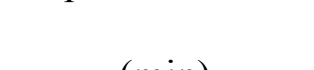 \\
\hline & concentration $(\%)$ & $(\mathrm{U} / \mathrm{g})$ & $(\min )$ \\
\hline 1 & 1 & 1 & 1 \\
\hline 2 & 2 & 2 & 2 \\
\hline 3 & 3 & 3 & 3 \\
\hline
\end{tabular}


Table 2 (on next page)

The results of orthogonal analysis of the liquefaction process 
1

\begin{tabular}{|c|c|c|c|c|}
\hline & A & B & $\mathrm{C}$ & \\
\hline $\begin{array}{c}\text { Experiment } \\
\text { number }\end{array}$ & $\begin{array}{c}\text { Starch slurry } \\
\text { concentration } \\
(\%)\end{array}$ & $\begin{array}{l}\text { The dosage of } \\
\text { liquefying } \\
\text { enzyme (U/g) }\end{array}$ & $\begin{array}{l}\text { Liquefaction } \\
\text { time (min) }\end{array}$ & DE value $(\%)$ \\
\hline 1 & $1 （ 15)$ & $1(15)$ & $1(10)$ & 11.01 \\
\hline 2 & 1 & $2(20)$ & $2(12)$ & 11.21 \\
\hline 3 & 1 & $3(25)$ & $3(14)$ & 12.03 \\
\hline 4 & $2(20)$ & 1 & 2 & 12.21 \\
\hline 5 & 2 & 2 & 3 & 12.33 \\
\hline 6 & 2 & 3 & 1 & 11.04 \\
\hline 7 & $3(25)$ & 1 & 3 & 13.02 \\
\hline 8 & 3 & 2 & 1 & 12.07 \\
\hline 9 & 3 & 3 & 2 & 12.45 \\
\hline
\end{tabular}




\section{Table 3 (on next page)}

Range analysis of the DE value 
1

\begin{tabular}{cccc}
\hline Serial number & A & B & C \\
\hline K1 & 11.33 & 12.03 & 11.97 \\
K2 & 11.95 & 11.94 & 11.69 \\
K3 & 12.45 & 11.77 & 12.08 \\
R & 1.12 & 0.26 & 0.39 \\
\hline
\end{tabular}

2 


\section{Table 4 (on next page)}

Enzymatic activities of the transglucosidases from different sources and the differences between the IMOs produced using the transglucosidases 
1

\begin{tabular}{ccc}
\hline Source of enzyme & Enzyme activity & Transglucosidation rate \\
This study & $(\mathrm{U} / \mathrm{mL})$ & $(\%)$ \\
\hline Amano Enzyme Inc., Japan & $3856 \pm 8.2$ & $6.69 \pm 0.2$ \\
Shanghai Co., Ltd. & $6015 \pm 12.3$ & $14.85 \pm 1.2$ \\
\end{tabular}
2 


\section{Table 5 (on next page)}

Differences between the IMOs produced in the present study and commercially available IMOs 
1

\begin{tabular}{ccc}
\hline Source of IMO & Glucose content (\%) & Oligosaccharide content \\
& & 41.74 \\
This study & 9.81 & 44.84 \\
Shandong Co., Ltd. & 0.0 & 36.78 \\
\hline Henan Co., Ltd. & 3.44 & \\
\hline
\end{tabular}

2 
Figure 1

The flow-process diagram of starch biotransformation into isomaltooligosaccharides using thermostable alpha-glucosidase from Geobacillus stearothermophilus

Source credit: Peng Chen.

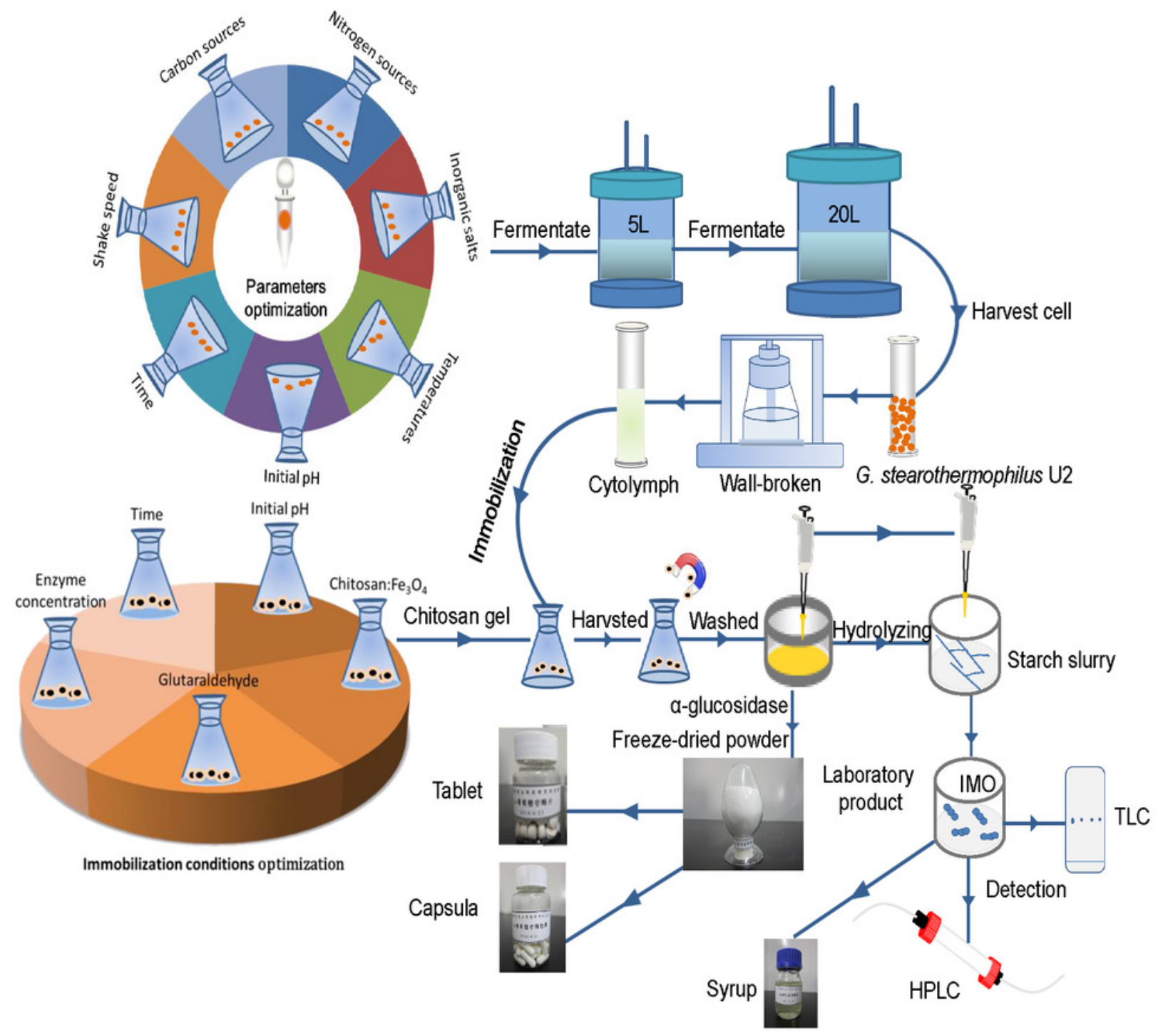




\section{Figure 2}

The effects of various environmental factors on bacterial enzyme production

(a) The effects of various carbon sources on enzyme production; (b) the effects of various nitrogen sources on enzyme production; (c) the effects of different temperatures on enzyme production; (d) the effects of different $\mathrm{pH}$ on enzyme production; and (E) the effects of different rotational speeds on enzyme production. 

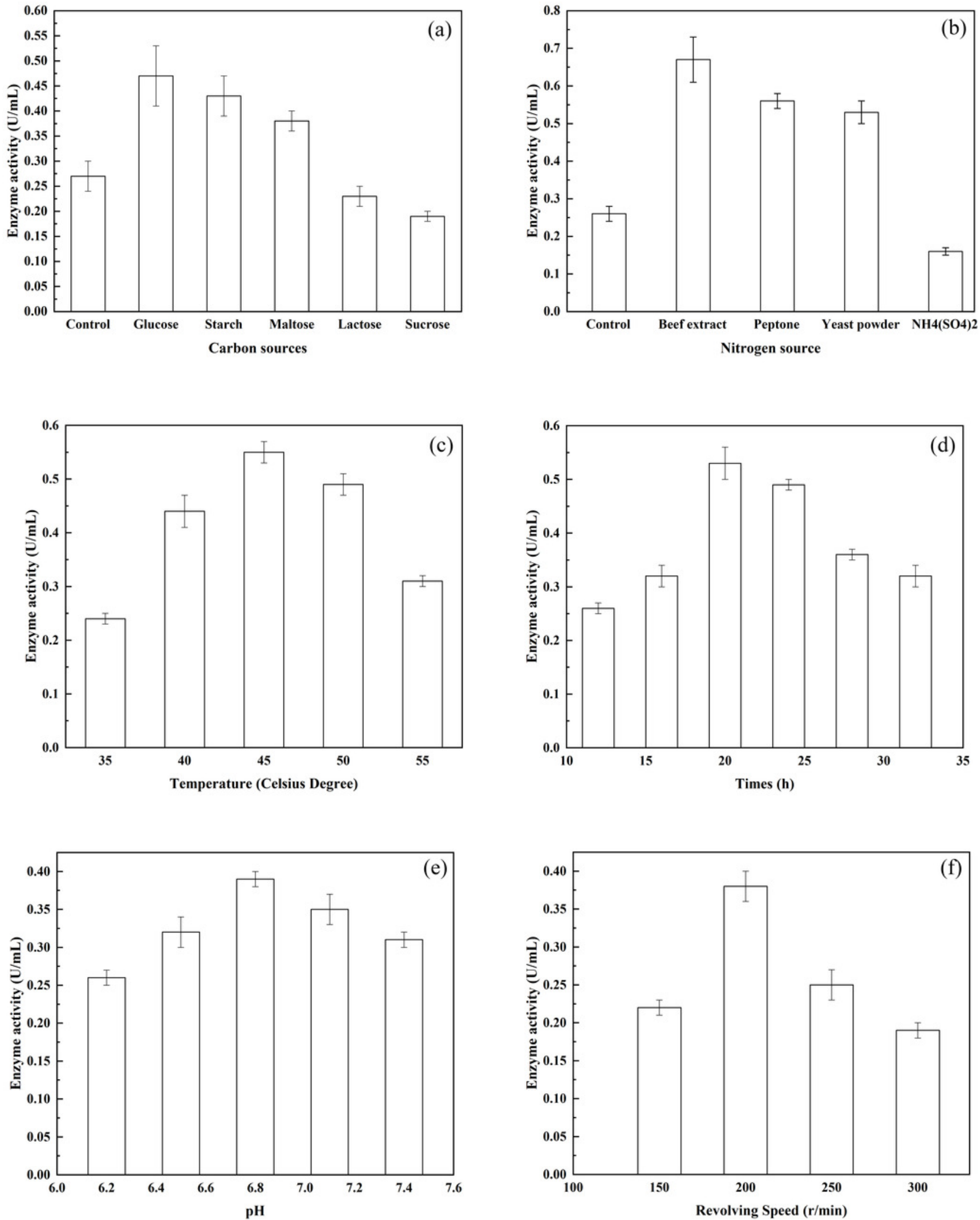


\section{Figure 3}

Immobilization of alpha-glucosidase on magnetic chitosan microspheres

(a) The effect of enzyme dosage on enzyme immobilization; (b) the effects of adsorption time on enzyme immobilization; (c) the effect of crosslinking temperature on enzyme immobilization; (d) the effect of glutaraldehyde concentration on enzyme immobilization; and (e) the effect of crosslinking time on enzyme immobilization. 

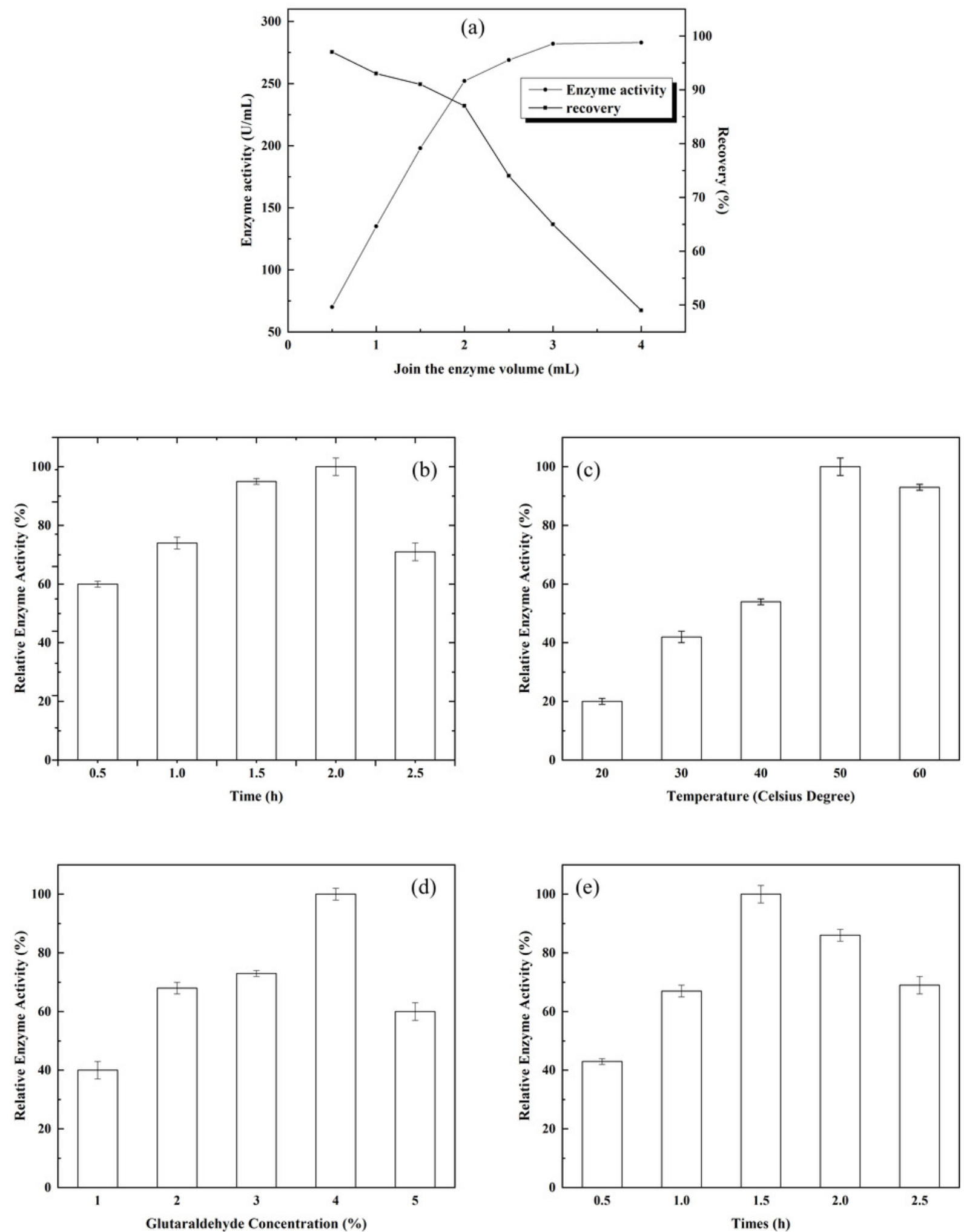
Figure 4

Optimization of the liquefaction process

(a) The effect of substrate concentration on DE value; (b) the effect of enzyme dosage on DE value; and (c) the effect of liquefaction time on DE value.
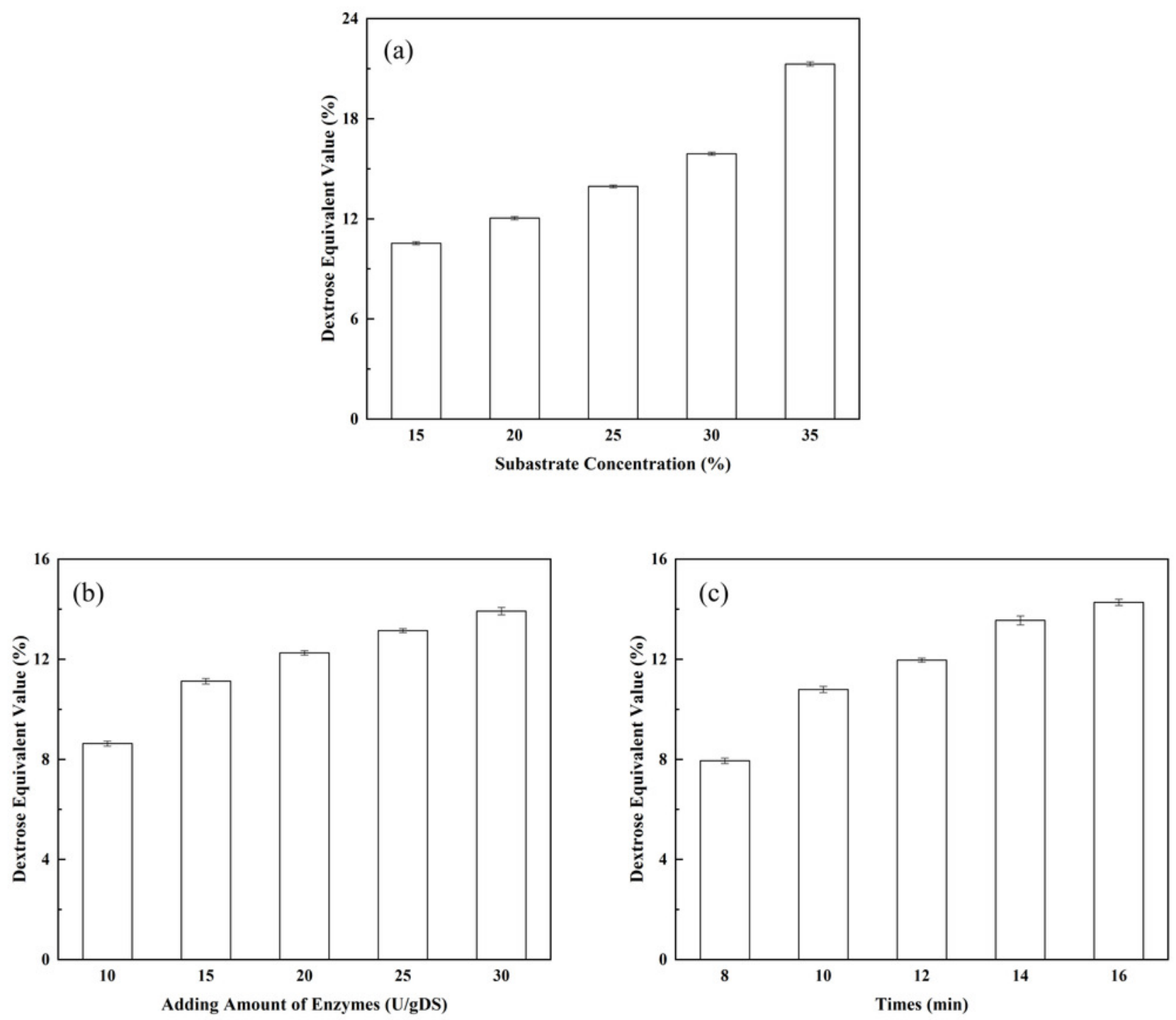


\section{Figure 5}

The effects of various saccharification conditions on IMO content

(a) Paper chromatography results showing the effect of glucoamylase dosage on IMO content. Lanes 1, 2, 3, 4, and 5 represent the different doses of glucoamylase used in the saccharification reaction ( $150 \mathrm{U} / \mathrm{g}, 200 \mathrm{U} / \mathrm{g}, 250 \mathrm{U} / \mathrm{g}, 300 \mathrm{U} / \mathrm{g}$ and $350 \mathrm{U} / \mathrm{g}$, respectively). G1, glucose; G2, maltose; G3, maltotriose; G4, maltotetraose. (b) Paper chromatography results showing the effects of saccharification time and transglycosidation process on IMO content. G1, glucose; G2, maltose; G3, maltotriose; G4, maltotetraose. Lanes 1, 2, 3, 4 and 5 represent various saccharification times ( $3.0 \mathrm{~h}, 3.5 \mathrm{~h}, 4.0 \mathrm{~h}, 4.5 \mathrm{~h}$ and $5.0 \mathrm{~h}$, respectively); lanes $6,7,8,9$ and 10 represent various doses of transglucosidase added to the reaction $(0.25 \mathrm{U} / \mathrm{g}, 0.50 \mathrm{U} / \mathrm{g}, 0.75 \mathrm{U} / \mathrm{g}, 1.00 \mathrm{U} / \mathrm{g}$ and $1.25 \mathrm{U} / \mathrm{g}$, respectively); lanes 11, 12, 13, 14 and 15 represent various transglycosidation times ( $38 \mathrm{~h}, 40 \mathrm{~h}, 42 \mathrm{~h}, 44 \mathrm{~h}$ and $48 \mathrm{~h}$, respectively); lane 16 represents the control (distilled water). 


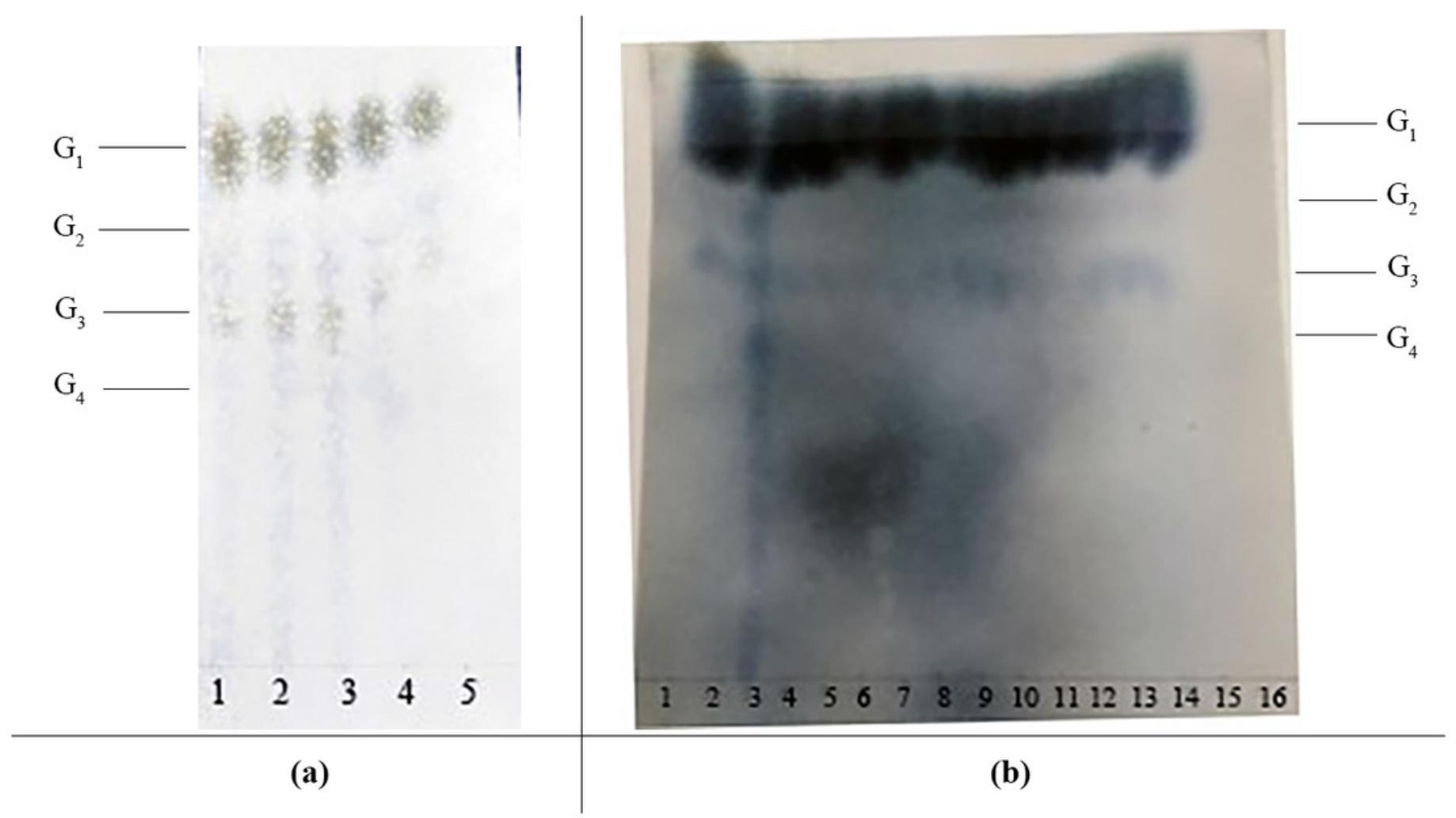




\section{Figure 6}

HPLC chromatograms of the IMOs prepared using enzymes from different sources

a: glucose; b: maltose; c: isomaltose; d: maltotriose; e: panose; f: isomaltotriose; $\mathrm{g}$ :

tetrasaccharide; h: pentasaccharide. (A) Chromatogram of the IMO syrup that was produced using the transglucosidase prepared in our laboratory; (B) chromatogram of the IMO syrup that was produced using the transglucosidase purchased from Japan; (C) chromatogram of the IMO syrup that was produced using the transglucosidase purchased from Shanghai Co., Ltd., China.
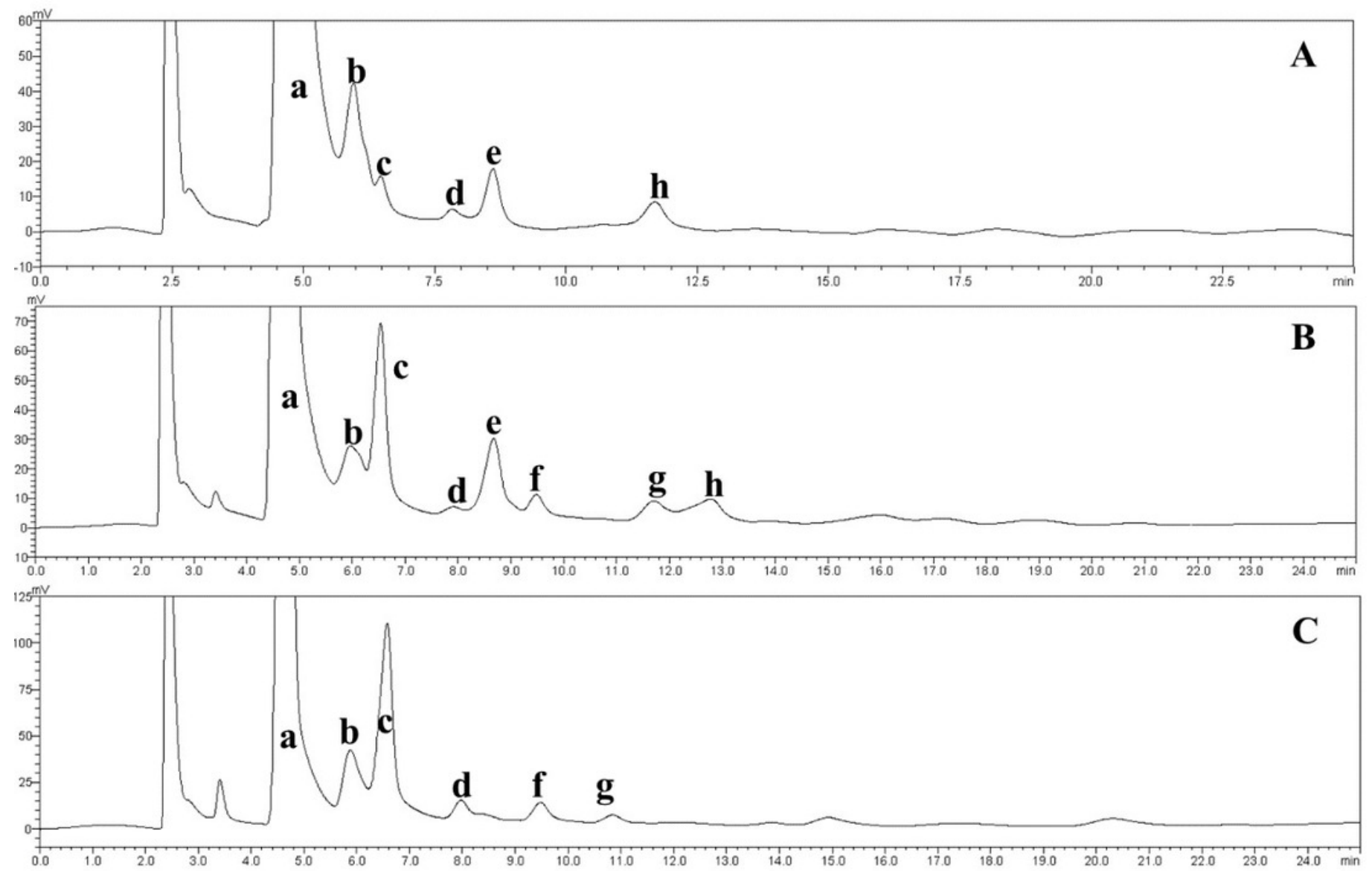
Figure 7

HPLC chromatograms of the IMOs from different sources.

a: glucose; b: maltose; c: isomaltose; $d$ : maltotriose; e: panose; f: isomaltotriose; $\mathrm{g}$ :

tetrasaccharide; $h$ : pentasaccharide. (A) Chromatogram of the IMO syrup prepared in this study; (B) Chromatogram of the IMO produced by Shandong Co., Ltd.; (C) chromatogram of the IMO produced by Henan Co., Ltd., China.
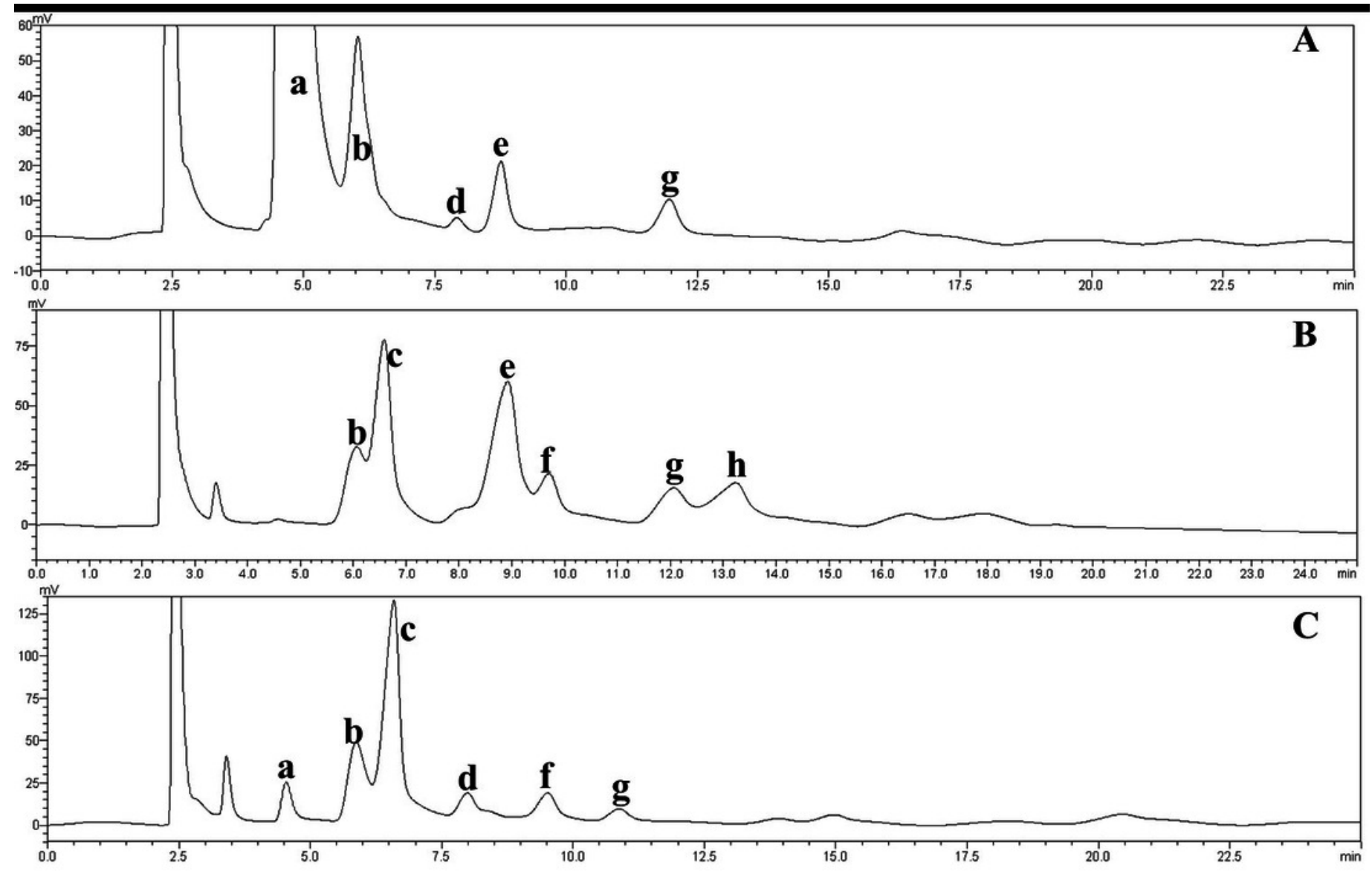